\title{
Impact of the City Park Revitalization and the Street Vendor Organization on the Level of Happiness of Pematangsiantar City Residents
}

\author{
Bahrudi Efendi Damanik ${ }^{1}$, Eka Irawan ${ }^{2}$ \\ \{bahrudiefendi@amiktunasbangsa.ac.id ${ }^{1}$ \} \\ Manajemen Informatika, AMIK Tunas Bangsa, Pematangsiantar, Indonesia ${ }^{1}$ \\ Sistem Informasi, STIKOM Tunas Bangsa, Pematangsiantar, Indonesia ${ }^{2}$
}

\begin{abstract}
Merdeka Square is one of the area in the heart of Pematangsiantar, a childfriendly open public space which has been around for hundreds of years to be a low-cost stress realving site for the people. The purpose of this study was to discover the impacts of the Revitalization of Child Friendly Open Public Space, the city park, the Street Vendors Arrangement on the happiness level of the city residents. This research is an associative type, with a sample of 272 respondents, using incidental sampling. The results of this study "have postive and significant effects on the residents' happiness: The park revitalization, $t$-count $>t$-table (5.046> 1.969), the partial arrangement of street vendors, $t$ count $>\mathrm{t}$-table $(8,452>1,969)$ and between the park revitalization variable and street vendor, F-count> F-table $(246,889>3,029)$. It turns out that happiness does not mean travelling, spending a lot of money on transportation, hotels, etc., but visiting a good City Park is another choice.
\end{abstract}

Keywords: City park revitalization, street vendor arrangement, happiness

\section{Introduction}

The Child-Friendly Integrated Public Space (RPTRA) in Pematangsiantar City which is best known to the public is the city park, popularly known by the local as Taman Bunga or Lapangan Merdeka. For two years (2017-2018), the city government carried out intense improvements to public facilities through its Public Housing and Settlement Service. The local Government transformed and fixed the City Park into a Green Open Space (RTH) that is more friendly to the whole residents of different races.

The residents visit the Park area every day, and usually the peak of the crowd occurs on Saturday nights, day time on Sundays and major holidays. Most of them bring their family and friends with them. This phenomenon leads to brief analyzes, that the public so far particularly require public places that can be used as a vehicle to make themselves and the family members happy. A nearby space that can be reached economically and can be used in the midst of their busy routine in fulfilling the necessities of life for themselves and their families.

The Revitalization of the park carried out by the City council on the Park was enthusiastically welcomed by the people. The arrangement made to this public space can clearly be seen with the visible improvement. This location is now equipped with various facilities and infrastructure, including children's playgrounds, fitness area, jogging tracks, skateboard tracks, as well as facilities provided for people with disabilities, and others. The trees that are allowed 
to grow create a feeling of comfort and give shade the visitors. The bright lights ascatering in the area eliminate the dim impression of nightlife.

The arrangement of street vendors along one side of the park allows the visitors to enjoy the atmosphere of the cool site, it also looks like it is getting organized, although some more improvements are needed here and there.

In a previous study conducted by [1], it was stated that the three aspects of life have the highest contribution to happiness are work $(11.91 \%)$, social relations $(11.39 \%)$ and family harmony $(11.28 \%)$. The weakness of this research is that it does not see that there are simple things that can actually make people happy: it is not only by seeing the financial amount of work done but also by utilizing public facilities provided by the government. Meanwhile [2] in his recommendation said that the development of urban forest and green open space must be carried out by the City Government through increasing the number, legalizing the area (location designation), and empowering the location of urban forest and green open space through plant enrichment and enhancing social and aesthetic functions. This of course has not maximized the use of green open space to increase the level of happiness of its citizens, but it is just wanting to increase the number green open-space areas.

\section{Method}

Judging the problems described in the introduction, the writers classsified this research as an associative type, namely a complete description of information about the relationship between one variable and another symptom (X1 is interactively related to X2 and Y) Sugiono in [3]. This research has a linear relationship because basically it wants to see the relationship between the independent variables, namely reading interest and the role of the consultant.

This research was carried out in Pematangsiantar city park and the research targets were visitors to the park. The object of this research was: "The Impact of city park Revitalization, and Arrangement of Street Vendors".

According to Sugiyono [4], "population is a generalization area consisting of objects/subjects that have certain qualities and characteristics that are determined by researchers to be studied and conclusions to be drawn". The population in this study were all visitors who had visited the RPTRA, because there was no official data released by the Public Housing and Settlement Service (PRKP) so it was considered an infinite population. "The table also shows that if the population is infinite, then the number of sample members for the error is $1 \%=664$, $5 \%=349$ and $10 \%=272 "$. For the sample in this study the researchers decided to take a sample of 272 people for an error rate of $10 \%$. The sampling technique uses incidental sampling, which is a sampling technique based on chance, that is, anyone who accidentally / incidentally meets the researcher can be used as a sample, if it is considered that the person who happened to be met is suitable as a data source [4]. 


\section{Results and Discussion}

\subsection{Presenting the results}

\subsubsection{Normality test}

The data normality test is intended to ensure that the sample data comes from a population with a norm distribution [5]. To see whether the data used in the study have been normally distributed, it can be seen with the one-sample Kolmogorov-Smirnov non-parametric test in the regression test results. This test aims to ascertain whether the residual value can be normally and independently distributed, we can see Table 1.

Tabel 1. Normality Test One-Sample Kolmogorov-Smirnov Test

\begin{tabular}{ll}
\hline & \multicolumn{1}{c}{ Unstandardized Residual } \\
\hline $\mathrm{N}$ & 272 \\
Asymp. Sig. (2-tailed) & $0.078 \mathrm{C}$ \\
\hline
\end{tabular}

From Table 1 above, it can be seen that the value belongs to Asymp. Sig (2-tailed) of 0.078, which means greater than 0.05 , can be interpreted that the residual value of the model can be declared to have been normally distributed.

\subsubsection{The relationship between the city park revitalization and the level of happiness of the citizens}

The t-test is conducted to determine the partial effect of each independent variable on the dependent variable whether it has a direct effect by directly comparing the probability value of each variable with a significant level of 0.05. For more details, we can see Table 2.

Tabel 2. Coefficientsa

\begin{tabular}{|c|c|c|c|c|c|}
\hline \multirow{2}{*}{ Model } & \multicolumn{2}{|c|}{$\begin{array}{c}\text { Unstandardized } \\
\text { Coefficients }\end{array}$} & \multirow{2}{*}{$\begin{array}{c}\begin{array}{c}\text { Standardized } \\
\text { Coefficients }\end{array} \\
\text { Beta }\end{array}$} & \multirow[t]{2}{*}{$\mathbf{T}$} & \multirow[t]{2}{*}{ Sig } \\
\hline & B & Std. Error & & & \\
\hline (Constant) & 13.172 & 1.442 & & 9.135 & 0.000 \\
\hline Park Revitalization & 0.248 & 0.049 & 0.315 & 5.046 & 0.000 \\
\hline
\end{tabular}

Source: Data processed in 2020

\subsubsection{The relationship of street vendor arrangement to the level of happiness of the citizen}

In the Table 3, there is a positive and significant relationship between the arrangement of street vendors and the level of happiness of city residents mentioned in the second hypothesis. 
Tabel 3. Coefficientsa

\begin{tabular}{|c|c|c|c|c|c|}
\hline \multirow[t]{2}{*}{ Model } & \multicolumn{2}{|c|}{$\begin{array}{l}\text { Unstandardized } \\
\text { Coefficients }\end{array}$} & Standardized Coefficients & \multirow[t]{2}{*}{$\mathbf{T}$} & \multirow[t]{2}{*}{ Sig. } \\
\hline & B & Std. Error & Beta & & \\
\hline (Constant) & 13.172 & 1.442 & & 9.135 & 0.000 \\
\hline $\begin{array}{l}\text { Street Vendor } \\
\text { Arrangment }\end{array}$ & 0.469 & 0.055 & 0.527 & 8.452 & 0.000 \\
\hline
\end{tabular}

Source: Data processed in 2020

In Table 3., can be seen that the street vendor arrangement has a t-test value of 8.452 which means it is greater than the t-table value of 1.969 or $t$-count> t-table $(8.452>1.969)$, then a significant regression coefficient is determined or HO is rejected. and the second is accepted, namely the variable PKL structuring partially positive and significant effect on the level of happiness of the city residents.

3.1.4 The relationship between the city park revitalization and street vendor arrangement on the level of happiness of citizens

Tabel 4. ANOVA

\begin{tabular}{lllllll}
\hline & Model & Sum of Squares & Df & Mean Square & F & Sig. \\
\hline \multirow{3}{*}{1} & Regression & 680.537 & 2 & 340.269 & 246.889 & $0.000 \mathrm{~b}$ \\
& Residual & 370.742 & 269 & 1.378 & & \\
\hline
\end{tabular}

a. Dependent Variable: Happiness

b. Predictors: (Constant), Street Vendor Arrangment, City Park Revitalization

To test the hypothesis there is a positive and significant relationship between City Park Revitalization and Street Vendor Arrangement, to the level of happiness of city residents, the independent variable is tested simultaneously on the dependent variable by doing the $\mathrm{F}$ test. the magnitude of the F-table value is 3.029 which means F-count> F-table (246,889> 3.029), so the research hypothesis can simultaneously prove that there is a positive and significant influence between the park Revitalization variable and Street Vendor Arrangement on the happiness level of the City residents.

\subsection{Discussion}

The results of this study prove that the happiness of residents is not only determined by three aspects of life that contribute to people's happiness, namely work, social relations, family harmony [1], but also there are other things that can be prepared by the city government; it is by providing the places to be used for a short recreation with their families in the midst of their being busy such as City Park.

This is in line with what was stated by [6], the city was developed by the Regional Government and managed in partnership with the community for the multi-functional public interest, among others, to fulfill children's rights to grow, to develop and to participate optimally in accordance with human dignity and to provide city infrastructure and facilities as a ChildFriendly City. 
Based on the results of this study, if indeed the street vendor arrangement is well organized, a special place is provided, the trading rules are regulated and cleanliness is prioritized, both traders and visitors will feel positive values, both in terms of economy and level of happiness.

In line with what was said by [7] that by providing facilities to street vendors by relocating traders in strategic places, but not disturbing the comfort of visitors, the local state will be able to create a format of cleanliness, beauty and tidiness of the city and the welfare and happiness of traders and visitors can be realized.

The results of this study support previous research conducted by [2]. With this result it can be understood that in fact, citizens in seeking happiness do not have to posses a lot of savings. If the City Government wants to synergize with its staff to provide lots of RPTRAs, then the city community will be able to minimize their level of stress in the midst of the current economic pressure and can enjoy a little happiness by visiting city park with their families without having to have a lot of money.

\section{Conclusion}

Revitalizing the city park will have a positive and significant effect on the happiness level of Pematangsiantar city residents. If the City Government adds another two or more city park, the city residents will have more than one choices to visit in order to relax their hearts and feelings in order to avoid stress in the midst of the current economic pressure.

The arrangement of street vendors has a positive and significant effect on the level of happiness of city residents. By relocating street vendors to strategic places to street vendors, making rules to prevent the street vendors from moving around, maintaining the cleanliness and tidiness of the park, it is hoped that the distribution and the increase of street vendors' income will raise, visitors will feel comfortable and have their level of happiness elevated.

The city park revitalization and street vendor arrangement simultaneously have a positive and significant effect on the happiness level of city residents. If the park Revitalization and street vendor Arrangement are carried out jointly, the common goal of the City Government and its citizens to create a city that is clean, green, safe, comfortable and child-friendly will be realized and the level of happiness of the city residents will be increased.

\section{References}

[1] Y. Hidayat, T. Purwandari, and A. Bachrudin, "Mengukur Indeks Kebahagiaan Penduduk Kota Bandung,” Pros. Semin. Nas. MIPA 2016, no. 2014, pp. 27-28, 2016.

[2] J. Silalahi and R. O. Situmorang, "Kebutuhan Hutan Kota dan Ruang Terbuka Hijau (RTH) di Kota Pematangsiantar," INOVASI, J. Polit. Dan Kebijak., vol. 3, no. 2, 2016.

[3] B. E. Damanik, "Pengaruh Motivasi Dan Pengembangan Diri Terhadap Prestasi Kerja Dosen,” J. EK BI Politek. Bisnis Indones., vol. 1, no. 1, pp. 23-24, 2018.

[4] Sugiono, Metode Penelitian Pendidikan Pendekatan Kuantitatif, R \& D, 15th ed. Bandung: Alfabeta, 2012.

[5] M. A. Dr. Sumanto, STATISTIKA TERAPAN, 1st ed. Yogyakarta, 2014.

[6] T. V. Indriany, "Skripsi Implementasi ruang publik terpadu ramah anak (rptra) di kelurahan sungai bambu kota administrasi jakarta utara," Univ. Sultan Ageng Tirtayasa, 2017.

[7] R. Saputra and E. Gunawan, "Analisis Kesejahteraan Pedagang Kaki Lima Di Kota Sigli Kabupaten Pidie,” J. Ilm. Mhs., vol. 4, no. 2, pp. 95-102, 2019. 